\title{
The effect of cognitive behavioural therapy on depression, anxiety, and stress in women with HIV
}

\author{
Atefeh Nobakht ${ }^{1}$, Minoo Mohraz ${ }^{2}$, Mitra Rahimzadeh ${ }^{3}$, Maryam Tehranizadeh ${ }^{4}$, \\ Zahra Behboodi-Moghadam ${ }^{5}$, Sara Esmaelzadeh-Saeieh ${ }^{6}$ \\ ${ }^{1}$ MS Student in Midwifery, Student Research Committee, Alborz University of Medical Sciences, Karaj, Iran \\ ${ }^{2}$ Iranian Research Center of HIV/AIDS, Iranian Institute for Reduction of High-Risk Behaviors, Tehran University of Medical \\ Sciences, Tehran, Iran \\ ${ }^{3}$ Social Determinants of Health Research Center, Alborz University of Medical Sciences, Karaj, Iran \\ ${ }^{4}$ Payam Noor University, Karaj, Iran \\ ${ }^{5}$ School of Nursing and Midwifery, Tehran University of Medical Sciences, Tehran, Iran \\ ${ }^{6}$ Social Determinants of Health Research Center, Faculty of Medical Sciences, Alborz University of Medical Sciences, Karaj, Iran
}

\begin{abstract}
Introduction: Considering the increase of human immunodeficiency virus (HIV)-infected women and their mental health concerns, the present study aimed at investigating the effect of cognitive behavioural therapy on stress, anxiety, and depression in women with HIV.

Material and methods: This randomised clinical trial was conducted on 60 women with HIV who referred to Imam Khomeini Hospital Consultation Centre for clients with risky behaviours in Tehran. The sampling method was census and samples were randomly assigned to two groups: control and intervention. In addition to routine care, the intervention group received six sessions of cognitive-behavioural counselling on mental health. The sampling period lasted from April to August 2017. The questionnaire used in this study was Depression Anxiety and Stress Scales (DASS-21).

Results: There was no statistically significant difference between the demographic characteristics in the control and intervention groups. The result of the repeated measurement test showed that the depression, anxiety, and stress in the intervention group changed over time, respectively $(p=0.002)$, $(p=0.000),(p=0.04)$, and there was a significant difference between the two groups, respectively $(p=0.003),(p=0.000),(p=0.000)$.

Conclusions: According to the results of this study and considering the prevalence of psychiatric disorders in people with HIV, cognitive behavioural therapy useful for counselling in women with HIV, and we suggest that cognitive behavioural therapy is provided in high risk behaviour counselling centre.
\end{abstract}

Key words: cognitive behavioural therapy, depression, anxiety, stress, HIV.

Address for correspondence: Dr. Sara Esmaelzadeh-Saeieh, Social Determinants of Health Research Center, Faculty of Medical Sciences, Alborz University of Medical Sciences, Karaj, Iran, phone: 00989126232569 ,

e-mail: esmaelzadeh1360@gmail.com
Article history:

Received: 05.04.2018

Received in revised form: 11.04.2018

Accepted: 11.04.2018

Available online: 15.08.2018
International Journal of HIV-Related Problems

HIV \& AIDS

R e vi e w 


\section{Introduction}

Annually, about 1.8 million adults are infected with human immunodeficiency virus (HIV) and 36.7 million people worldwide are living with acquired immune deficiency syndrome (AIDS), of which 17.8 million are women over the age of 15 years [1]. It is estimated that there are 90,000 HIV-infected people in Iran, of which 26,000 are women over 15 years of age. According to the formal HIV-infected statistics, 34,949 cases were reported up to April of 2017, 17\% being young women [2]. HIV infection, due to stress issues such as illness disclosure [3], drug use, various tests, abnormal social problems, stigma and discrimination, leads to a lot of problems in the mental health of patients with HIV [4]. Common mental disorders are associated with poor HIV outcomes such as lack of adherence to treatment and illness. The results of a study on 200 individuals showed that anxiety and depression is higher in infected women than men [5]. People with HIV are highly vulnerable and in need social support from family and community [6]. Cognitive behavioural therapy (CBT) helps patients identify and control their distressed thoughts and fears [7]. Studies have shown that CBT in HIV-infected people reduces their depression, stress, and anxiety $[8,9]$.

A review study showed that CBT has no effect on depression, anxiety, and stress among people with HIV [10]. Using psychosocial screening tools such as the Depression Anxiety and Stress Scales (DASS-21) questionnaire can help to identify more people [11]. Considering the relationship between HIV and high-risk sexual behaviours [12, 13], the increasing population of HIV-infected women and their mental health concerns, an important component of reproductive health [14], this study was conducted to investigate the effect of CBT counselling on stress, anxiety, and depression in women with HIV.

\section{Material and methods}

This study was a randomised controlled trial. Participants in this study were all HIV-positive women referring to Imam Khomeini Hospital Consultation Centre for clients with risky behaviours. This centre is a referral counselling centre, and people visit this centre from different parts of the province and even the country. In this centre, there are 300 cases of HIV-infected women who, after consulting with a midwife of the centre, found that there were 66 active files in the centre (Figure 1). Some people visit this centre only to receive medication and hide their illness from other people in their cities and do not have enough time to visit and receive counselling regularly. Thus, the sample size in this study was 66 people using the census method. The sampling period lasted from April to August 2017. The inclusion criteria in this study included being Iranian, being in the reproductive age of 15-45 years, being diagnosed for more than six months of illness, and being literate. The exclusion criteria were having an addiction and being unable to respond to questionnaires, having a history of mental disorders and severe psychiatric problems confirmed by a physician, advanced stage of HIV disease, getting a normal score from all three parts of the stress, anxiety, and depression questionnaire, and not attending more than one session of the training session.

The researcher was a student in MS counselling midwifery, who had trained the field of CBT. After obtaining

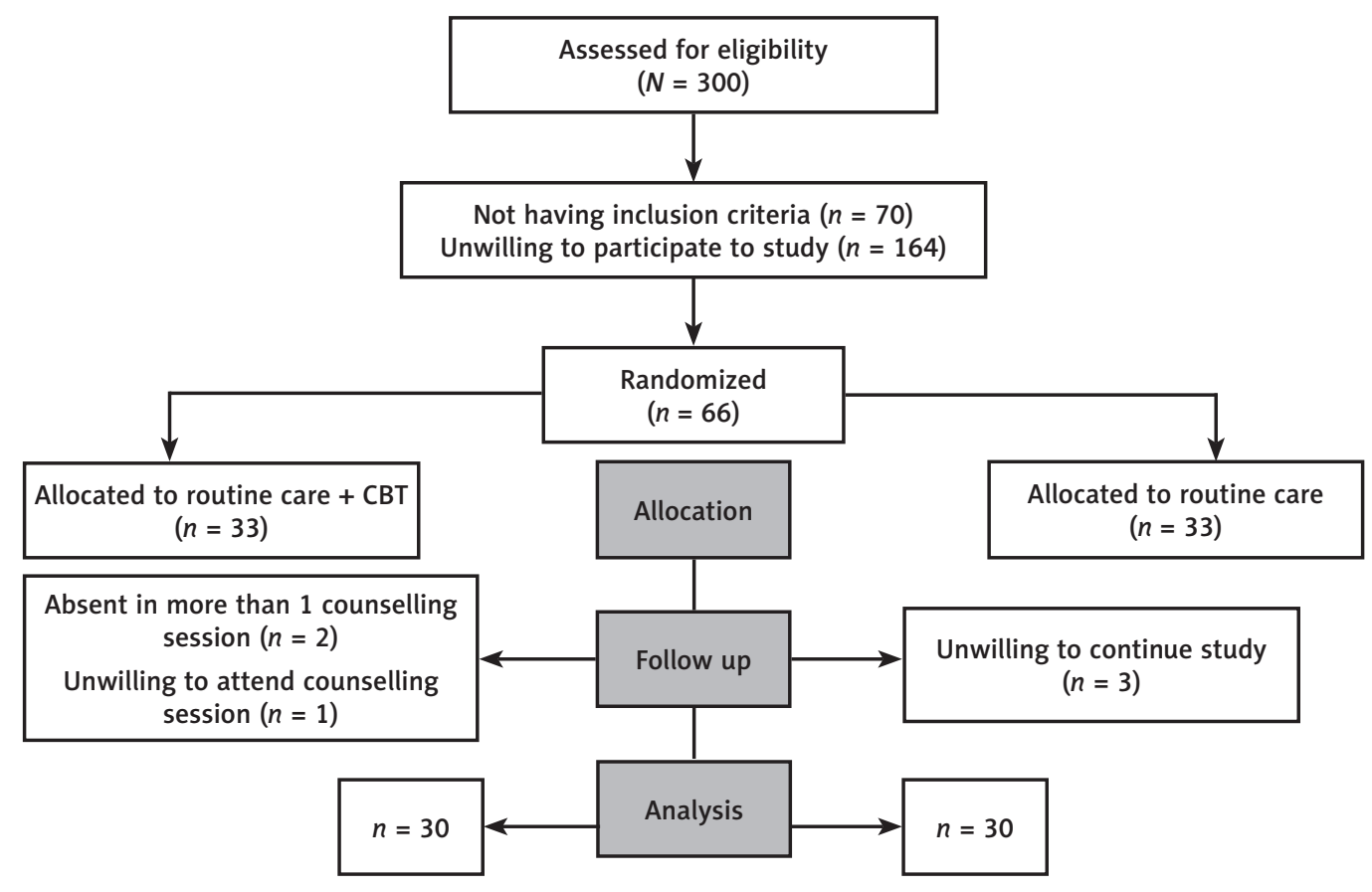

Fig. 1. Consort flow diagram of study 
necessary permission from the faculty and the university, each participant was called by phone, and after explaining the objectives and obtaining oral consent, the samples, according to recorded file, were randomly assigned to two groups; even numbers were specified to the control group and odd numbers to the intervention group based on table numbers. Counselling group (intervention) and routine care group (receiving medication, family planning services, and laboratory tests) (control) group. After determining the groups, and before the study started, written consent was obtained from each woman, and before the beginning of the intervention, the total scores of mental disorder in the two groups were determined by questionnaire (DASS-21). The intervention group was divided to three sub-groups and were trained in six counselling sessions with a cognitive-behavioural approach to anxiety, stress, and depression that lasted for 90 minutes two times a week. Follow-up of counselling sessions was conducted by phone. The content of the sessions was confirmed by the faculty members of Midwifery, Psychiatry, and Psychology and included the following:

Session 1: Asking about the illness and feeling that they experienced when they were found infected. The patients attitudes and beliefs about HIV. Session 2: Patient's awareness of the impact of the disease on the person's body and mind, the ways of coping with it, unpleasant experiences that had a negative impact on mental health. Session 3: Questions about the psychological problems that people have been facing, identification of individuals' desires to change their relationships with others. Talking about behaviours that cause patients to be disrupted and providing strategies and practices to encounter them, and recommending participation in group sessions in behavioural counselling centres. Session 4: Explanation of individual mental and emotional enhancement strategies, reducing stress, mental concentration, and relaxation. Session 5: Repeating of previous exercises, explaining the discrimination and stigma, and coping with them. Informing individuals about positive thinking and avoiding negative thoughts. Session 6: Repeating previous exercises, summing up previous sessions.

1. The data gathering tool had two parts: the first part was related to demographic characteristics, and the second part was related to stress, anxiety, and depression, based on the DASS21 questionnaire, which has 21 items (seven items per domain), and was created by Loviband and Loviband [15]. Henry and Crawford validated the DASS questionnaire with good Cronbach's a values for depression, anxiety, and stress of $0.88,0.82$, and 0.9 , respectively [16]. In Iran, Behboodi et al. used this questionnaire in people with HIV. DASS 21 is four-point Likert scale, the severity of each of the domains is calculated by summing all the items and subsequently multiplying by two. The cut-off levels to determine the possible presence of depression, anxiety, and stress are $>9,>7$, and $>14$, respectively [5].

2. In order to observe ethics in research, control group participants received a booklet of advice, given after the end of the study.
Table 1. Demographic characteristic of participants

\begin{tabular}{|c|c|c|c|}
\hline \multirow[b]{2}{*}{ Variable } & Intervention & Control & \multirow[b]{2}{*}{$p$ value } \\
\hline & $\begin{array}{c}\text { Frequency } \\
\text { (\%) }\end{array}$ & $\begin{array}{c}\text { Frequency } \\
\text { (\%) }\end{array}$ & \\
\hline \multicolumn{4}{|l|}{ Age } \\
\hline $20-24$ & $0(0.0)$ & $2(6.7)$ & \multirow[t]{5}{*}{$0.8^{*}$} \\
\hline $25-29$ & $6(20.0)$ & $2(6.7)$ & \\
\hline $30-34$ & $4(13.3)$ & $4(13.3)$ & \\
\hline $35-39$ & $8(26.7)$ & $13(43.3)$ & \\
\hline $40-45$ & $12(40.0)$ & $9(30.0)$ & \\
\hline
\end{tabular}

Education

\begin{tabular}{l|c|c|c}
\hline Primary school & $7(23.3)$ & $5(16.7)$ & \multirow{2}{*}{$0 / 5^{* *}$} \\
\hline Secondary & $8(26.7)$ & $4(13.3)$ & \\
\hline High school & $6(20.0)$ & $6(20.0)$ & \\
\hline Diploma & $7(23.3)$ & $11(36.7)$ & \\
\hline University & $2(6.7)$ & $4(13.3)$ & \\
\hline
\end{tabular}

Job

\begin{tabular}{l|c|c|c}
\hline House keeper & $19(63.3)$ & $20(66.7)$ & \multirow{2}{*}{$0.5^{* * *}$} \\
\cline { 1 - 2 } Jobless & $6(20.0)$ & $4(13.3)$ & \\
\hline Worker & $0(0.0)$ & $1(3.3)$ & \\
\hline Employer & $3(10.0)$ & $1(3.3)$ & \\
\cline { 1 - 2 } Self-employment & $2(6.7)$ & $4(13.3)$ & \\
\hline
\end{tabular}

\begin{tabular}{|c|c|c|c|}
\hline \multicolumn{4}{|l|}{ Partners status } \\
\hline Positive & $18(60.0)$ & $16(53.3)$ & \multirow[t]{2}{*}{$0.8^{* * *}$} \\
\hline Negative & $10(33.3)$ & $10(33.3)$ & \\
\hline \multicolumn{4}{|l|}{ Transmission } \\
\hline Spouse & $22(73.3)$ & $19(63.3)$ & \multirow[t]{4}{*}{$0.2^{\star \star \star}$} \\
\hline Addiction & $0(0.0)$ & $4(13.3)$ & \\
\hline Sex with others & $4(13.3)$ & $3(10.0)$ & \\
\hline Others & $4(13.3)$ & $4(13.3)$ & \\
\hline
\end{tabular}

Marital status

\begin{tabular}{l|c|c|c}
\hline Single & $11(36.7)$ & $9(30.0)$ & \multirow{2}{*}{$0.9^{* * *}$} \\
\cline { 1 - 2 } Married & $15(50.0)$ & $17(56.7)$ & \\
\cline { 1 - 2 } Divorcee & $2(6.7)$ & $3(10.0)$ & \\
\cline { 1 - 2 } Widow & $2(6.7)$ & $1(3.3)$ & \\
\hline
\end{tabular}

\begin{tabular}{|c|c|c|c|}
\hline \multicolumn{4}{|l|}{ Duration of HIV } \\
\hline Under 1 year & $0(0.0)$ & $2(6.7)$ & \multirow[t]{4}{*}{$0 / 1^{* * \star}$} \\
\hline 2-5 years & $22(73.3)$ & $15(50.0)$ & \\
\hline $6-10$ years & $4(13.3)$ & $10(30.0)$ & \\
\hline 10 years and more & $4(13.3)$ & $3(10.0)$ & \\
\hline
\end{tabular}

Addiction

\begin{tabular}{|c|c|c|c|}
\hline Yes & $3(10.0)$ & $4(13.3)$ & \multirow[t]{2}{*}{$0.1^{\star \star \star}$} \\
\hline No & $27(90.0)$ & $26(86.7)$ & \\
\hline \multicolumn{4}{|c|}{ Treatment status } \\
\hline On ART & $26(86.7)$ & $28(93.3)$ & \multirow[t]{2}{*}{$1.0^{\star *}$} \\
\hline Not on ART & $4(13.3)$ & $2(6.7)$ & \\
\hline
\end{tabular}


Table 2. Trend of depression severity before, after, and one month after cognitive behavioural therapy

\begin{tabular}{|c|c|c|c|c|c|c|c|c|}
\hline \multirow{2}{*}{$\begin{array}{l}\text { Depression } \\
\text { severity }\end{array}$} & \multicolumn{2}{|c|}{$\begin{array}{c}\text { Before } \\
\text { Frequency (\%) }\end{array}$} & \multicolumn{2}{|c|}{$\begin{array}{c}\text { After } \\
\text { Frequency (\%) }\end{array}$} & \multicolumn{2}{|c|}{$\begin{array}{l}\text { One month after } \\
\text { Frequency (\%) }\end{array}$} & \multicolumn{2}{|c|}{$\begin{array}{l}\text { Repeated measure } \\
\text { (Greenhouse-Geisser) }\end{array}$} \\
\hline & Intervention & Control & Intervention & Control & Intervention & Control & $\begin{array}{l}\text { Between } \\
\text { group }\end{array}$ & $\begin{array}{l}\text { Within } \\
\text { group }\end{array}$ \\
\hline Normal & $6(20)$ & $2(6.7)$ & $9(30)$ & $3(10)$ & $11(36.6)$ & $1(3.3)$ & \multirow{6}{*}{$\begin{array}{c}\mathrm{F}=6.6 \\
p=0.003\end{array}$} & \multirow{6}{*}{$\begin{array}{c}\mathrm{F}=6.9 \\
p=0.002\end{array}$} \\
\hline Mild & $6(20)$ & $7(23.3)$ & $11(36.6)$ & $5(16.6)$ & $7(23.3)$ & $7(23.3)$ & & \\
\hline Moderate & $13(43.4)$ & $8(26.7)$ & $8(26.6)$ & $11(36.6)$ & $9(30)$ & $10(33.3)$ & & \\
\hline Severe & $4(13.3)$ & $12(40)$ & $2(6.6)$ & $10(33.3)$ & $2(6.6)$ & $11(36.6)$ & & \\
\hline Very severe & $1(3.3)$ & $1(3.3)$ & $0(3.3)$ & $1(3.3)$ & $1(3.3)$ & $1(3.3)$ & & \\
\hline Mean \pm SD & $31.1 \pm 11.9$ & $36.1 \pm 12.1$ & $24.9 \pm 10$ & $35.1 \pm 11.4$ & $25.9 \pm 11.1$ & $37.5 \pm 11.6$ & & \\
\hline Muchly test & & & & & & & 0. & 2 \\
\hline
\end{tabular}

Table 3. Trend of anxiety severity before, after and one month after cognitive behavioural therapy

\begin{tabular}{|c|c|c|c|c|c|c|c|c|}
\hline \multirow{2}{*}{$\begin{array}{l}\text { Anxiety } \\
\text { severity }\end{array}$} & \multicolumn{2}{|c|}{$\begin{array}{c}\text { Before } \\
\text { Frequency (\%) }\end{array}$} & \multicolumn{2}{|c|}{$\begin{array}{c}\text { After } \\
\text { Frequency (\%) }\end{array}$} & \multicolumn{2}{|c|}{$\begin{array}{l}\text { One month after } \\
\text { Frequency (\%) }\end{array}$} & \multicolumn{2}{|c|}{$\begin{array}{l}\text { Repeated measure } \\
\text { (Greenhouse-Geisser) }\end{array}$} \\
\hline & Intervention & Control & Intervention & Control & Intervention & Control & $\begin{array}{l}\text { Between } \\
\text { group }\end{array}$ & $\begin{array}{l}\text { Within } \\
\text { group }\end{array}$ \\
\hline Normal & $2(6.6)$ & 0 & $5(16.6)$ & $1(3.3)$ & $6(20)$ & 0 & \multirow{6}{*}{$\begin{array}{c}F=10 \\
p=0.000\end{array}$} & \multirow{6}{*}{$\begin{array}{c}\mathrm{F}=12.9 \\
p=0.000\end{array}$} \\
\hline Mild & 0 & $1(3.3)$ & $8(26.7)$ & 0 & $6(20)$ & 0 & & \\
\hline Moderate & $14(46.6)$ & $8(26.7)$ & $11(36.6)$ & $7(23.3)$ & $10(33.3)$ & $6(20)$ & & \\
\hline Severe & $9(30)$ & $12(40)$ & $5(16.6)$ & $13(43.4)$ & $6(20)$ & $14(46.6)$ & & \\
\hline Very severe & $5(16.6)$ & $1(3.3)$ & $1(3.3)$ & $9(30)$ & $2(6.7)$ & $9(30)$ & & \\
\hline Mean \pm SD & $30.2 \pm 10$ & $34.5 \pm 10.4$ & $22.7 \pm 8.1$ & $33 \pm 8$ & $23.7 \pm 10$ & $35.6 \pm 8$ & & \\
\hline Muchly test & & & & & & & & \\
\hline
\end{tabular}

Table 4. Trend of stress severity before, after, and one month after cognitive behavioural therapy

\begin{tabular}{|c|c|c|c|c|c|c|c|c|}
\hline \multirow{2}{*}{$\begin{array}{l}\text { Stress } \\
\text { severity }\end{array}$} & \multicolumn{2}{|c|}{$\begin{array}{c}\text { Before } \\
\text { Frequency (\%) }\end{array}$} & \multicolumn{2}{|c|}{$\begin{array}{c}\text { After } \\
\text { Frequency (\%) }\end{array}$} & \multicolumn{2}{|c|}{$\begin{array}{l}\text { One month after } \\
\text { Frequency (\%) }\end{array}$} & \multicolumn{2}{|c|}{$\begin{array}{l}\text { Repeated measure } \\
\text { (Sphericity assumed) }\end{array}$} \\
\hline & Intervention & Control & Intervention & Control & Intervention & Control & $\begin{array}{l}\text { Between } \\
\text { group }\end{array}$ & $\begin{array}{l}\text { Within } \\
\text { group }\end{array}$ \\
\hline Normal & $9(30)$ & $7(23.3)$ & $13(43.4)$ & $3(10)$ & $14(46.6)$ & 0 & \multirow{5}{*}{$\begin{array}{c}\mathrm{F}=3.3 \\
p=0.04\end{array}$} & \multirow{5}{*}{$\begin{array}{c}\mathrm{F}=5.3 \\
p=0.000\end{array}$} \\
\hline Mild & $8(26.7)$ & $5(16.6)$ & $8(26.7)$ & $6(20)$ & $8(26.7)$ & $2(6.6)$ & & \\
\hline Moderate & $10(33.3)$ & $13(43.4)$ & $8(26.7)$ & 17 (56.6) & $6(20)$ & $20(66.6)$ & & \\
\hline Severe & $3(10)$ & $5(16.6)$ & $1(3.3)$ & $4(13.3)$ & $2(6.6)$ & $7(23.3)$ & & \\
\hline Mean \pm SD & $35.7 \pm 10.5$ & $39.6 \pm 10.4$ & $31.6 \pm 10.9$ & $40.9 \pm 9.2$ & $31.5 \pm 11.4$ & $45.8 \pm 6$ & & \\
\hline Muchly test & & & & & & & & 5 \\
\hline
\end{tabular}

\section{Ethical considerations}

The study was registered in the Iranian Registry of Clinical trials (registration code: IRCT2015101920719N3). Furthermore, the Institutional Review Board and the Ethics Committee of Alborz University of Medical Sciences, Karaj, Iran approved the study (approval codes: 95-01-03-1384 and Abzums.Rec.1395.150, respectively). All women were ensured about the confidentiality of their personal information. All of them provided informed consent for participa- tion. We attempted to protect the patient's rights according to the Declaration of Helsinki.

\section{Results}

The demographic characteristics of the participants in the study are listed in Table 1 . The result of repeated measure test showed that depression in the intervention group changed over time $(p=0.002)$, and there was a significant difference between the two groups $(p=0.003)$ (Table 2$)$. 
The result of repeated measure test showed that anxiety changed over time in the intervention group $(p<0.001)$, and there was a significant relationship between the two groups $(p<0.001)$ (Table 3).

The result of repeated measure test showed that the stress variable in the intervention group changed over time $(p<0.001)$, and there was a significant difference between the two groups $(p=0.04)$.

\section{Discussion}

The prevalence of depression, anxiety, and stress before intervention, respectively, were: $3.3 \%, 10 \%$, and 0 - very severe; $26.6 \%, 35 \%$, and $13.3 \%$ - severe; and $35 \%, 36.6 \%$, and $38.3 \%$ - moderate (Tables 2, 3, and 4). In a study on 206 people with HIV, the prevalence of depression, anxiety, and stress was reported as $36.9 \%, 45.1 \%$, and $26.7 \%$, respectively. Among those with these psychological problems, the majority had moderate to extremely severe symptoms of depression (71.1\%), anxiety (88.2\%), and stress (72.27\%) [17]. The prevalence of mental disorders among people with chronic diseases is higher than in the general population, leading to unusual functional and health problems [18]. The results of a study among HIV-positive women showed that the high prevalence of depression in this group was due to factors such as life instability, fear of death, stigma, discrimination, difficult conditions, forced caring for a spouse, and tolerance of antiretroviral drugs [19].

The results of repeated measurements showed that cognitive-behavioural counselling was effective in depression severity (Table 2). In one study, CBT were used to reduce the symptoms of depression in people affected by HIV, and the symptoms were reduced significantly and patient adherence to antiretroviral therapy [20].

The results of the repeated measure test showed the effect of cognitive-behavioural counselling on the anxiety of infected women (Table 3). Patients with HIV were more likely to develop anxiety due to family, occupational, and economic problems [21]. In an intervention study in Sub-Saharan Africa using CBT, the results of interventions on mental health indicated a significant reduction in anxiety, and increased self-confidence and self-acceptance [22].

The results of the repeated measure test showed the effect of cognitive-behavioural counselling on the stress of infected women (Table 4). A study showed the effect of cognitive-behavioural counselling and stress management on reducing depression, stress, and anxiety effects [8]. The results of this study showed the effect of cognitive-behavioural counselling on stress, anxiety, and depression in women with HIV. In a psychological approach study in China on three groups of people with HIV (CBT, group support, and group counselling), the results showed that CBT had a better effect on people's psychological mood, including depression, anxiety, and stress [23]. Regarding the duration of the study's effectiveness one month after the end of counselling sessions, stress, anxiety, and depression scores decreased compared to before the intervention. In another study, the effectiveness of cognitive-behavioural counselling on mental health was reported to range from six to 12 weeks [24]. Among the limitations of this research, lack of control during after-intervention follow-up sessions for participation in educational interventions via the Internet [25], other researchers, or club-assistance classes should be mentioned.

\section{Conclusions}

Considering the results of this study and other studies, and taking into account the prevalence of mental disorders in people with HIV, it is suggested that CBT be included in the counselling services of risky behaviours. In this way, the mental health of the affected patients and their quality of life will increase and the harm to other members of the family and society will be reduced.

\section{Conflict of interest}

The authors declare no potential conflicts of interest with respect to the research, authorship, and/or publication of this article.

\section{References}

1. UNAIDS. Latest statistics on the status of the AIDS epidemic 2017. Available from: www.unaids.org/sites/default/files/media_asset/ UNAIDS_FactSheet_en.

2. CDC. Unpublished AIDS report. Iranian Ministry of Health and Medical Education, 2017.

3. Saeieh SE, Ebadi A, Mahmoodi Z, et al. Barriers to disclosure of disease in HIV-infected women: a qualitative study. HIV AIDS Rev 2018; 17: 12-17.

4. Wekesa E. A new lease of life: sexual and reproductive behaviour among PLWHA in the ART era in Nairobi slums. London School of Economics and Political Science, 2012.

5. Saadat M, Behboodi ZM, Saadat E. Comparison of depression, anxiety, stress, and related factors among women and men with human immunodeficiency virus infection. J Hum Reprod Sci 2015; 8: 48.

6. Shacham E, López JD, Önen NF, Overton ET. The Relationship of Social Support and Neighborhood Perceptions among Individuals with HIV. J Int Assoc Provid AIDS Care 2017; 16: 440-445.

7. Hofmann SG, Sawyer AT, Fang A. The empirical status of the "new wave" of cognitive behavioral therapy. Psychiatr Clin North Am 2010; 33: 701-710.

8. Sabet AH, Khalatbari J, Ghorbani MA, et al. Group training of stress management vs. group cognitive-behavioral therapy in reducing depression, anxiety and perceived stress among HIV-positive men. Iran J Psychiatry Behav Sci 2013; 7: 4-8.

9. Safren SA, O'Cleirigh C, Tan JY, et al. A randomized controlled trial of cognitive behavioral therapy for adherence and depression (CBTAD) in HIV-infected individuals. Health Psychol 2009; 28: 1-10.

10. Van der Heijden I, Abrahams N, Sinclair D. Psychosocial group interventions to improve psychological well-being in adults living with HIV. Cochrane Database Syst Rev 2017; 3: CD010806.

11. Arseniou S, Arvaniti A, Samakouri M. HIV infection and depression. Psychiatry Clin Neurosci 2014; 68: 96-109.

12. Nobakht A, Mohraz M, Rahimzadeh M, et al. The effect of cognitive -behavioural therapy on the reproductive health of women with HIV: a randomised controlled trial. HIV AIDS Rev 2017; 16: 236-243.

13. Paz-Bailey G, Miller W, Shiraishi RW, et al. Reaching men who have sex with men: a comparison of respondent-driven sampling and 
time-location sampling in Guatemala City. AIDS Behav 2013; 17: 3081-3090.

14. Behboodi-Moghadam Z, Esmaelzadeh-Saeieh S, Ebadi A, et al. Development and Psychometric Evaluation of a Reproductive Health Assessment Scale for HIV-Positive Women. Shiraz E-Medical Journal 2016;17(6).

15. Lovibond SH, Lovibond PF. Manual for the depression anxiety stress scales. Psychology Foundation of Australia, Sydney 1995.

16. Henry JD, Crawford JR. The short-form version of the Depression Anxiety Stress Scales (DASS-21): Construct validity and normative data in a large non-clinical sample. Br J Clin Psychol 2005; 44: 227-239.

17. Radzniwan R, Alyani M, Aida J, et al. Psychological status and its clinical determinants among people living with HIV/AIDS (PLWHA) in Northern Peninsular Malaysia. HIV AIDS Rev 2016; 15: 141-146.

18. Egede LE. Major depression in individuals with chronic medical disorders: prevalence, correlates and association with health resource utilization, lost productivity and functional disability. Gen Hosp Psychiatry 2007; 29: 409-416.

19. Mello VA, Segurado AA, Malbergier A. Depression in women living with HIV: clinical and psychosocial correlates. Arch Womens Ment Health 2010; 13: 193-199.

20. Himelhoch S, Medoff D, Maxfield J, et al. Telephone based cognitive behavioral therapy targeting major depression among urban dwelling, low income people living with HIV/AIDS: results of a randomized controlled trial. AIDS Behav 2013; 17: 2756-2764.

21. Petrushkin H, Boardman J, Ovuga E. Psychiatric disorders in HIV-positive individuals in urban Uganda. Psychiatrist 2005; 29: 455-458.

22. Pretorius L, Gibbs A, Crankshaw T, Willan S. Interventions targeting sexual and reproductive health and rights outcomes of young people living with HIV: a comprehensive review of current interventions from sub-Saharan Africa. Global Health Action 2015; 8: 28454 .

23. Molassiotis A, Callaghan P, Twinn S, et al. A pilot study of the effects of cognitive-behavioral group therapy and peer support/counseling in decreasing psychologic distress and improving quality of life in Chinese patients with symptomatic HIV disease. AIDS Patient Care STDS 2002; 16: 83-96.

24. Chibanda D, Cowan FM, Healy JL, et al. Psychological interventions for Common Mental Disorders for People Living With HIV in Low-and Middle-Income Countries: systematic review. Trop Med Int Health 2015; 20: 830-839.

25. Esmaelzadeh S, Jahdi F, Haghani H, Saeieh S. Access to internet and using for health information in women's that referred to $\mathrm{He}$ alth Centers of Universities in Tehran City. Aus J Basic Applied Sci 2011; 5: 1204-1208. 